\title{
SUSTAINABILITY PERFORMANCE EVALUATION IN BUILDING PROJECTS BY INTEGRATING LEAN AND SUSTAINABLE MANAGEMENT USING THE DELPHI METHOD
}

\author{
Fiorela Cruzado-Ramos ${ }^{1}$ and Xavier Brioso ${ }^{2}$
}

\begin{abstract}
This research paper aims to contribute to the improvement of sustainable management of Peruvian buildings throughout the project lifecycle by integrating the Lean Construction philosophy and sustainability concepts through the Delphi method. First, the literature is reviewed and the existing information on compatibility or synergy between Lean Construction and sustainability management systems is analyzed. After that, with the support of a collaborating company, a methodology for evaluating sustainability performance in projects is developed, which integrates the Last Planner ${ }^{\circledR}$ System and sustainability management. The proposed tool is validated by the Delphi method, for which we solicited expert opinions on the study topics. Next, the proposed methodology protocols corresponding to the evaluation of the design, construction, and use phases of the buildings are developed. Finally, the methodology is applied to five case studies, the results are analyzed, and the methodology is validated. Throughout the research, the principles, tools, techniques, and practices of the Lean philosophy are analyzed, which synergize with the methodologies, standards, and tools of sustainability management.
\end{abstract}

\section{KEY WORDS}

Lean Construction, Environmental Sustainability, Key Performance Indicators, Delphi Method, Buildings

\section{INTRODUCTION}

The Lean Construction philosophy allows improving the traditional construction management model, based on strategies regarding all types of waste in production, time, and effort in order to generate the maximum amount of possible value (Koskela et al. 2002; Ballard and Howell 2003; Jørgensen et al. 2007; Mossman 2009). On the one hand, Lean Construction achieves sustainability in projects in its three pillars: economic, due to the resources and costs reduction; social, by allowing health, safety, good work environment, and loyalty among interested parties; and environmental, by eliminating waste, reducing pollution, and preserving resources (Kim et al. 2007), (Peng et al. 2011).

GETEC Research Group, Department of Engineering, Pontifical Catholic University of Peru, Lima, Peru, fiorela.cruzado@pucp.edu.pe, orcid.org/0000-0003-3979-6838

2 GETEC Research Group, Department of Engineering, Pontifical Catholic University of Peru, Lima, Peru, xbrioso@pucp.edu.pe, orcid.org/0000-0002-0174-0241 
On the other hand, the construction sector is primarily responsible for $\mathrm{CO}_{2}$ (Degani and Cardoso 200; Horvath 2004), the pollutant gas emitted by human activity (Francis et al. 2019). The Stern report (2006) indicates that the climate change risks are equivalent to losing $5 \%$ of the world's annual GDP. Furthermore, the construction management presents problems related to low levels of productivity and high costs (Koskela 2000; Hussin et al. 2013). Therefore, it is necessary to study construction management principles and practices allowing to create and preserve the environmental, economic, and social values (Brioso and Patricio 2017; Brioso 2011; Solaimini 2019).

This study proposes the integration of the Lean philosophy and sustainability management applied to real building projects, in order to promote its advantages and boost its use in the industry (Carvajal et al. 2019). This research paper aims to contribute to the improvement of sustainable management of Peruvian buildings throughout the project lifecycle by developing and applying a sustainability performance evaluation methodology, integrated by Lean Construction and sustainable management using the Delphi method.

\section{RESEARCH METHOD}

The method consists of developing and applying a methodology based on the processes of the model proposed by Cruzado (2019), whose processes are: (1) Identify the research objective; (2) Propose a sustainability performance evaluation methodology of the building projects; (3) Validate the proposed methodology; (4) Apply the generated tool; (5) Evaluate results; and (6) Report results. Figure 1 depicts the described methodology.

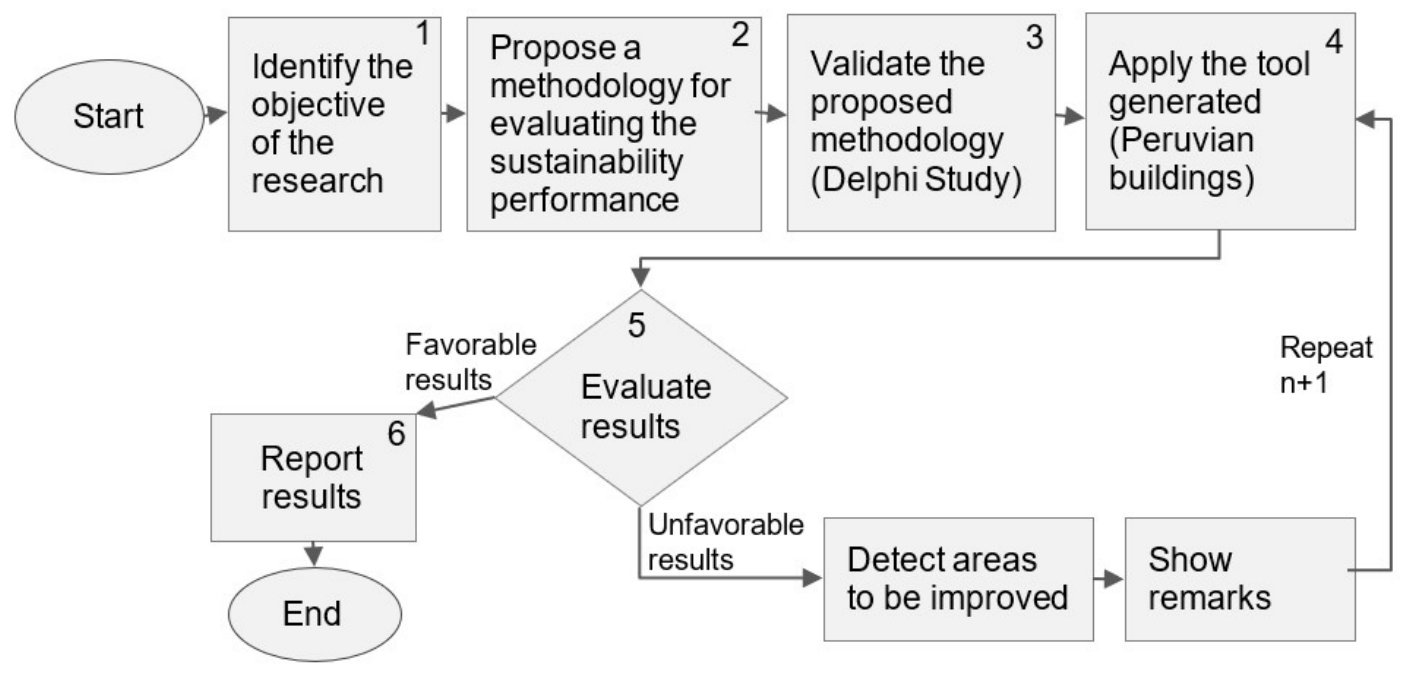

Figure 1: Research Process

\section{LEAN CONSTRUCTION}

Lean practices are important in the construction projects development (Ansah and Sorooshian 2017) because their implementation allows reducing construction times and costs, achieving higher productivity, better quality, and greater value for the customer; reducing the consumption of material resources, water, and energy; reducing the emission of particles, noise, and waste; and improving working conditions, health and safety at work, interpersonal relationships, and the communication (Vieira de Carvalho et al. 2017), (Weinheimer et al. 2017) 


\section{SUSTAINABILITY}

Sustainability considers a balance between the economic, social, and environmental dimensions, also known as "triple bottom line" (Elkington 2013). During the construction phase, the sustainability economic dimension seeks to maximize the project budget by minimizing operation and maintenance costs. The social dimension aims to improve the health, safety, and welfare conditions of workers in the workplace (Rajendran et al. 2009). The environmental dimension focuses on reducing the consumption of resources and the waste of materials and energy resulting from construction activities (Koranda et al. 2012). Some sustainability aspects, actually those derived from construction activities having some type of environmental impact, were considered here for the evaluation and control of the sustainable performance of building construction projects, which are applicable in the different phases of the project lifecycle, according to the criteria followed in this study.

\section{ENVIRONMENTAL SUSTAINABILITY}

The construction industry generates the progressive deterioration of the environment because its activities generate an irreversible impact on the natural environment (United Nations Environment 2018). Sustainability and its application in the development of construction projects are of interest to scholars and professionals in the construction field.

The concept of sustainability refers to the necessary reconciliation between the demand for welfare associated with the idea of development and conservation of natural support systems (Du Pisani 2006). Human activities cannot stress the ecosystem beyond the limit from which irreversible degradation phenomena are activated (Manzini and Bigues 2000). Currently, different studies are carried out promoting construction with environmental responsibility, e.g. Li et al. 2020, carried out a study where they stated that the industrialized construction is a method balancing the three dimensions of TBL in the Chinese construction industry.

\section{LEED CERTIFICATION}

The LEED Certification (Leadership in Energy and Environmental Design) promotes compliance with sustainability criteria and environmental care. The considerations involve the efficient use of water, energy saving, the selection of local and sustainable materials, the care of the environment during construction and air quality (Scofield 2013). At the same time, Horman and Col. (2006) and Lapinski et al. (2006) suggest that by implementing Lean construction practices, the delivery overall performance of LEED certified buildings could be improved. Similarly, Carneiro et al. (2012) developed a correlation matrix between the Lean construction principles and the LEED rating system for new constructions.

\section{DELPHI METHODOLOGY}

The Delphi method is a decision-making method following an iterative process and is carried out by anonymous experts led by the facilitator presenting comments and analyzes the results. According to Landeta (2006), the Delphi method was rapidly accepted and spread because it provided valuable solutions to the problems inherent in the group traditional opinion, based on direct interaction, that is, a reduction in the influence of some undesirable psychological effects among the participants (inhibition, dominant personalities, etc.), selective feedback of the relevant information, more extensive consideration thanks to repetition, statistical results, flexible methodology and simple execution. Hallowell and Gambatese (2010) point out that the procedures to be taken into 
account for the Delphi study implementation are: (1) Identify the research objective; (2) Identify the potential panel of experts and make the selection according to the predefined criteria; (3) Develop questionnaires; (4) Transmit the questionnaire to the panel of experts; (5) Gather and analyze responses; and (6) Evaluate consensus.

A flow chart summarizing the procedures described is shown in Figure 2.

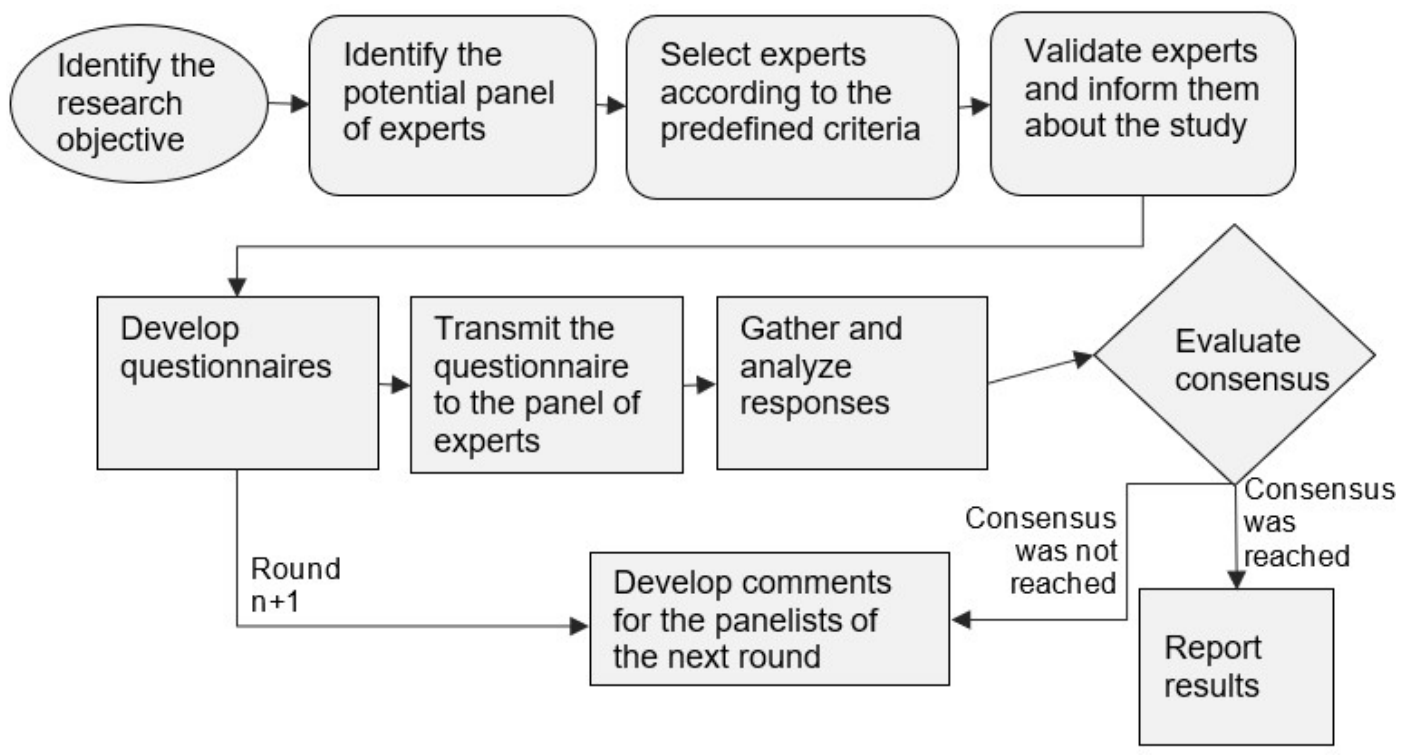

Figure 2: Delphi Method (Hallowell and Gambatese 2010)

The parameters to be taken into account in a Delphi study are described below:

\section{Professional Profiles of Experts}

Each research has special characteristics that condition the criteria to be used in order to determine the number and profile of the members in the panel of experts (Hsu; Sandford 2007). These authors recommend that those invited to participate must be aware of the problem to be analyzed and willing to make positive contributions.

\section{Experience Level}

Similarly, it is recommended to take into account the experience level according to their professional profile (Cortés et al. 2012), considering that the most important factor to take into account in the formation of the panel is the experience of its members.

\section{Variability of the Experts Panel}

The panel of experts must comprise a multidisciplinary team according to the study requirements, the participation of first level experts, whether national or international, which will allow to enrich the study, since it is desirable to have, in the study, as the greatest equivalence as possible and facilitate the benchmarking.

\section{Number of the Experts Panel}

Some authors (Cortes et al. 2012) argue that, according to the latest applications related to construction management, the average number of experts must be 16 , with a minimum of 10. The minimum number of rounds so that the consensus can be achieved is two. The questionnaire can be sent in paper, email, or personal interview (according to the preference of the expert). In the application of the Delphi technique, it is important to 
have the feedback between one round and the other in order to achieve consensus among the anonymous members of the panel. Without this iteration, the study could not be valid.

\section{CASE STUDIES AND RESULTS}

\section{IDENTIFY THE OBJECTIVE OF THE RESEARCH}

The objective is to contribute to improving the sustainable management of Peruvian buildings throughout the lifecycle of the project by integrating the Lean Construction philosophy and sustainability concepts using the Delphi method.

\section{PROPOSE A SUSTAINABILITY PERFORMANCE EVALUATION METHODOLOGY IN BUILDING PROJECTS}

Through the help of a collaborating company that implements Last Planner System in its works and the analysis of the existing literature, it was possible to establish an initial proposal involving the measurement of key sustainability performance indicators (KPIs), which is shown in the Table 2.

\section{VALIDATE THE PROPOSED METHODOLOGY}

Through the application of a Delphi study that involved a multidisciplinary panel of experts (Table 1), it was possible to revalidate the proposed tool, which allows the evaluation of sustainability performance in building projects.

Table 1: Profile characteristics of the expert panel members

\begin{tabular}{|c|c|c|c|c|c|}
\hline Position & $\begin{array}{l}\text { Year } \\
\text { Exp. }\end{array}$ & Profession & $\begin{array}{l}\text { Level of } \\
\text { Education }\end{array}$ & Sector & Category \\
\hline Specialist in Sustainability & 9 & Architect & $\begin{array}{l}\text { Master's } \\
\text { Degree }\end{array}$ & Private & Consultant \\
\hline Specialist in Sustainability & 16 & Architect & $\begin{array}{l}\text { Professional } \\
\text { Degree }\end{array}$ & Private & Consultant \\
\hline Projects and Innovation & 10 & Architect & $\begin{array}{l}\text { Master's } \\
\text { Degree }\end{array}$ & Private & Stockholder \\
\hline Executive Coordinator & 7 & Design & $\begin{array}{l}\text { Master's } \\
\text { Degree }\end{array}$ & Private & Consultant \\
\hline Construction Manager & 18 & $\begin{array}{c}\text { Civil } \\
\text { Engineer }\end{array}$ & $\begin{array}{l}\text { Master's } \\
\text { Degree }\end{array}$ & Private & Builder \\
\hline General Manager & 10 & Architect & $\begin{array}{l}\text { Professional } \\
\text { Degree }\end{array}$ & Private & Administrator \\
\hline Project Manager & 24 & $\begin{array}{c}\text { Civil } \\
\text { Engineer }\end{array}$ & $\begin{array}{l}\text { Master's } \\
\text { Degree }\end{array}$ & Private & Administrator \\
\hline Project Supervisor & 10 & $\begin{array}{c}\text { Civil } \\
\text { Engineer }\end{array}$ & $\begin{array}{l}\text { Professional } \\
\text { Degree }\end{array}$ & Private & Supervisor \\
\hline Project Supervisor & 15 & $\begin{array}{c}\text { Civil } \\
\text { Engineer }\end{array}$ & $\begin{array}{l}\text { Professional } \\
\text { Degree }\end{array}$ & Private & Supervisor \\
\hline
\end{tabular}




\begin{tabular}{cccccc}
\hline Plant Professor & 13 & Architect & $\begin{array}{c}\text { Doctor's } \\
\text { Degree }\end{array}$ & Private & Scholar \\
Plant Professor & 11 & $\begin{array}{c}\text { Civil } \\
\text { Engineer }\end{array}$ & $\begin{array}{c}\text { Doctor's } \\
\text { Degree }\end{array}$ & Private & Scholar \\
$\begin{array}{c}\text { Plant Professor. } \\
\text { Project Consultant }\end{array}$ & 25 & $\begin{array}{c}\text { Civil } \\
\text { Engineer }\end{array}$ & $\begin{array}{c}\text { Doctor's } \\
\text { Degree }\end{array}$ & Private & Scholar \\
$\begin{array}{c}\text { Teaching, Projects - } \\
\text { Innovation }\end{array}$ & 14 & Architect & $\begin{array}{c}\text { Master's } \\
\text { Degree }\end{array}$ & Private & Scholar \\
Project Supervisor & 13 & $\begin{array}{c}\text { Civil } \\
\text { Engineer } \\
\text { Professional } \\
\text { Degree }\end{array}$ & Private & Supervisor \\
Project Manager & 15 & Architect & $\begin{array}{c}\text { Master's } \\
\text { Degree }\end{array}$ & Private & Consultant \\
Project Manager & 30 & Civil & $\begin{array}{c}\text { Master's } \\
\text { Degree }\end{array}$ & Private & Constructor \\
\hline
\end{tabular}

The questionnaire for the Delphi study is shown below.

\section{QUESTIONNAIRE:}

a) A list of indicators by project phase is shown. It is requested to review them, and, if necessary, recommend changes in them or propose other indicators that are considered important.

b) In the empty boxes of the column corresponding to "recommended minimum", it is requested to establish a minimum value based on the indicator under analysis.

c) In the empty boxes of the column corresponding to "average", it is requested to rank the indicators according to their importance level (range from 1 to 100 points)

Table 2: Sustainability performance indicators of the building project (Design)

\begin{tabular}{|c|c|c|c|}
\hline Phase & & Indicators & Metrics \\
\hline \multirow[t]{3}{*}{ Design } & 1 & $\begin{array}{c}\mathrm{N}^{\circ} \text { of meetings of planning of the Project } \\
\text { sustainability }\end{array}$ & $\mathrm{Id}=\frac{\mathrm{N}^{\circ} \text { of executed meetings }}{\mathrm{N}^{\circ} \text { of projected meetings }}$ \\
\hline & 2 & $\mathrm{~N}^{\circ}$ of credits for project sustainability & Id $=\frac{\text { Obatined design credits }}{\text { Desired design credits }}$ \\
\hline & 3 & $\begin{array}{c}\text { Compatibility between the areas of } \\
\text { design, production and environmental } \\
\text { management }\end{array}$ & It is compatible or not compatible \\
\hline \multirow[t]{4}{*}{ Constr. } & 4 & $\begin{array}{c}\mathrm{N}^{\circ} \text { of meetings between areas of } \\
\text { production and environmental }\end{array}$ & $I d=\frac{\mathrm{N}^{\circ} \text { of executed meetings }}{\mathrm{N}^{\circ} \text { of meetings projected }}$ \\
\hline & 5 & $\begin{array}{c}\mathrm{N}^{\circ} \text { of meetings for environmental } \\
\text { management training }\end{array}$ & $\mathrm{Id}=\frac{\mathrm{N}^{\circ} \text { of executed trainings }}{\mathrm{N}^{\circ} \text { of meetings projected }}$ \\
\hline & 6 & $\begin{array}{l}\text { Participation of area of environmental } \\
\text { management in the meetings of LPS } \\
\text { programming or production }\end{array}$ & Participate or not participate \\
\hline & 7 & $\begin{array}{l}\text { Coordination between the area of } \\
\text { environmental management and } \\
\text { production }\end{array}$ & Frequency \\
\hline
\end{tabular}




\begin{tabular}{|c|c|c|c|}
\hline & 8 & Time required for coordination meetings & Time in minutes \\
\hline & \multirow[t]{2}{*}{9} & \multirow{2}{*}{$\begin{array}{l}\text { Update of the environmental } \\
\text { management plan according to the } \\
\text { update of the production schedule }\end{array}$} & $\mathrm{N}^{\circ}$ of envi. manag. plan update made \\
\hline & & & $\mathrm{N}^{\circ}$ of production updates \\
\hline & \multirow[t]{2}{*}{10} & \multirow{2}{*}{$\begin{array}{c}\text { Percentage of environmental monitoring } \\
\text { carried out with respect to those } \\
\text { programmed }\end{array}$} & $\mathrm{N}^{\circ}$ of monitoring executed \\
\hline & & & $\mathrm{N}=\overline{\mathrm{N}^{\circ} \text { of monitoring projected }}$ \\
\hline & \multirow[t]{2}{*}{11} & \multirow{2}{*}{$\begin{array}{c}\text { Percentage of environmental } \\
\text { inspections executed with respect to } \\
\text { those scheduled }\end{array}$} & $\mathrm{N}^{\circ}$ of executed inspections \\
\hline & & & $\mathrm{N}=\overline{\mathrm{N}^{\circ} \text { of inspections projected }}$ \\
\hline & \multirow[t]{2}{*}{12} & \multirow{2}{*}{$\begin{array}{l}\text { Percentage of control measures } \\
\text { implemented with respect to those } \\
\text { programmed }\end{array}$} & $\mathrm{N}^{\circ}$ of implemented control measures \\
\hline & & & $\mathrm{N}^{\circ}$ of programmed control measures \\
\hline & \multirow[t]{2}{*}{13} & \multirow{2}{*}{$\begin{array}{l}\text { Percentage of meetings executed with } \\
\text { respect to those scheduled }\end{array}$} & $\mathrm{N}^{\circ}$ of executed meetings \\
\hline & & & $I a=\overline{\mathrm{N}^{\circ} \text { of programmed meetings }}$ \\
\hline & \multirow[t]{2}{*}{14} & \multirow{2}{*}{$\begin{array}{c}\text { Percentage of mitigation measures } \\
\text { implemented with respect to those } \\
\text { programmed }\end{array}$} & $\mathrm{N}^{\circ}$ of mitigation meas. implemented \\
\hline & & & $\overline{\mathrm{N}^{\circ} \text { of programmed control measures }}$ \\
\hline & \multirow[t]{2}{*}{15} & \multirow{2}{*}{$\begin{array}{l}\text { Percentage of audits performed with } \\
\text { respect to those scheduled }\end{array}$} & $\mathrm{N}^{\circ}$ of executed audits \\
\hline & & & $=\overline{\mathrm{N}^{\circ} \text { of programmed audits }}$ \\
\hline & \multirow[t]{2}{*}{16} & \multirow{2}{*}{$\begin{array}{c}\mathrm{N}^{\circ} \text { of nonconformities reported in } \\
\text { inspections, analysis of their root causes } \\
\text { and corrective measures }\end{array}$} & $\mathrm{N}^{\circ}$ of corrective measures implemented \\
\hline & & & $\mathrm{N}^{\circ}$ corrective measures required \\
\hline & \multirow[t]{2}{*}{17} & \multirow{2}{*}{$\begin{array}{l}\mathrm{N}^{\circ} \text { of nonconformities reported in } \\
\text { internal audits, analysis of their root } \\
\text { causes and corrective measures }\end{array}$} & $\underline{\mathrm{N}^{\circ} \text { of corrective measures implemented }}$ \\
\hline & & & $\mathrm{N}^{\circ}$ of corrective measures required \\
\hline & \multirow[t]{2}{*}{18} & \multirow[t]{2}{*}{$\mathrm{N}^{\circ}$ of credits for project sustainability } & $\mathrm{Id}=\underline{\text { Construction } \text { credits obtained }}$ \\
\hline & & & Desired construction credits \\
\hline & 19 & Air pollution (PM2.5 particulate material) & Air, PM2.5 $\leq 50.00 \mu \mathrm{g} / \mathrm{m}^{3}$ \\
\hline & 20 & Air pollution (PM10) & Air, PM10 $\leq 100.00 \mu \mathrm{g} / \mathrm{m}^{3}$ \\
\hline & 21 & Noise pollution (diurnal noise) & Diurnal noise $\leq 70 \mathrm{LAeqT}$ \\
\hline & 22 & Noise pollution (nocturnal noise) & Nocturnal noise $\leq 60$ LAeqT \\
\hline & 23 & $\begin{array}{l}\text { Solids residues management: Primary } \\
\text { storage and temporary collection points }\end{array}$ & Complies or does not comply \\
\hline & 24 & $\begin{array}{l}\text { Solids residues management: } \\
\text { Classification of solids residues }\end{array}$ & Complies or does not comply \\
\hline & 25 & $\begin{array}{c}\text { Solids residues management: } \\
\text { Collection, transport and final disposal of } \\
\text { solid residue }\end{array}$ & Complies or does not comply \\
\hline \multirow[t]{6}{*}{ Use } & \multirow[t]{2}{*}{26} & \multirow[t]{2}{*}{$\mathrm{N}^{\circ}$ of installations quality inspections } & $\mathrm{N}^{\circ}$ of executed inspections \\
\hline & & & $\overline{\mathrm{N}^{\circ} \text { of programmed inspections }}$ \\
\hline & \multirow[t]{2}{*}{27} & \multirow[t]{2}{*}{$\mathrm{N}^{\circ}$ of equipment operation inspections } & $\mathrm{Id}=\frac{\mathrm{N}^{\circ} \text { of executed inspections }}{}$ \\
\hline & & & $\overline{\mathrm{N}^{\circ} \text { of programmed inspections }}$ \\
\hline & \multirow[t]{2}{*}{28} & \multirow{2}{*}{$\begin{array}{c}\mathrm{N}^{\circ} \text { of preventive maintenance of the } \\
\text { installations }\end{array}$} & $\mathrm{Id}=\frac{\mathrm{N}^{\circ} \text { of executed maintenance }}{}$ \\
\hline & & & $\overline{\mathrm{N}^{\circ} \text { of programmed maintenance }}$ \\
\hline
\end{tabular}




\begin{tabular}{ccc}
\hline 29 & $\mathrm{~N}^{\circ}$ corrective maintenance of the \\
installations
\end{tabular}$\quad \mathrm{Id}=\frac{\mathrm{N}^{\circ} \text { of executed maintenance }}{\mathrm{N}^{\circ} \text { of programmed maintenance }}$

The results after running two rounds of the Delphi Method are shown in Table 3.

Table 3: Tool to evaluate the project sustainability performance

\begin{tabular}{|c|c|c|c|c|c|}
\hline \multicolumn{2}{|c|}{ Phase } & Indicators & Minimum & Average & Score \\
\hline \multirow{3}{*}{ 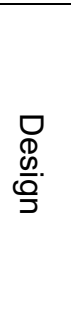 } & 1 & $\begin{array}{c}\mathrm{N}^{\circ} \text { of meetings of planning of the Project } \\
\text { sustainability }\end{array}$ & Fortnightly & 96 & 5.28 \\
\hline & 2 & $\mathrm{~N}^{\circ}$ of credits for Project sustainability & Not applicable & 90 & 4.94 \\
\hline & 3 & $\begin{array}{c}\text { Compatibilization between areas of design, } \\
\text { production and environmental } \\
\text { management }\end{array}$ & Not applicable & 97 & 5.32 \\
\hline \multirow{14}{*}{ 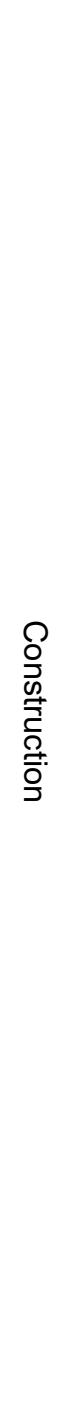 } & 4 & $\begin{array}{c}\mathrm{N}^{\circ} \text { of meetings between areas of } \\
\text { production and environmental } \\
\text { management }\end{array}$ & Twice a week & 90 & 4.96 \\
\hline & 5 & $\mathrm{~N}^{\circ}$ of credits for Project sustainability & Not applicable & 94 & 5.18 \\
\hline & 6 & $\begin{array}{l}\mathrm{N}^{\circ} \text { of meetings for environmental } \\
\text { management training }\end{array}$ & Weekly & 81 & 4.43 \\
\hline & 7 & $\begin{array}{c}\text { Participation of area of environmental } \\
\text { management in the meetings of LPS } \\
\text { programming (Last Planner System) or } \\
\text { production }\end{array}$ & Weekly & 87 & 4.77 \\
\hline & 8 & $\begin{array}{l}\text { Update of environmental management plan } \\
\text { according to update of production } \\
\text { programming }\end{array}$ & Weekly & 86 & 4.73 \\
\hline & 9 & $\begin{array}{l}\mathrm{N}^{\circ} \text { of environmental monitorings carried } \\
\text { out regarding those programmed }\end{array}$ & Quarterly & 80 & 4.39 \\
\hline & 10 & $\begin{array}{l}\mathrm{N}^{\circ} \text { of monitorings carried out with results } \\
\text { below the LMP of air/ } \mathrm{N}^{\circ} \text { of monitorings of } \\
\text { air programmed }\end{array}$ & Quarterly & 83 & 4.56 \\
\hline & 11 & $\begin{array}{l}\mathrm{N}^{\circ} \text { of monitorings carried out with results } \\
\text { below the LMP of noise / } \mathrm{N}^{\circ} \text { of monitorings } \\
\text { of noise programmed }\end{array}$ & Quarterly & 83 & 4.53 \\
\hline & 12 & $\begin{array}{l}\text { Management of solid wastes: Primary } \\
\text { storage and points of temporary gathering }\end{array}$ & Not applicable & 80 & 4.37 \\
\hline & 13 & $\begin{array}{l}\text { Management of solid wastes: Classification } \\
\text { of residues of solid wastes }\end{array}$ & Not applicable & 86 & 4.72 \\
\hline & 14 & $\begin{array}{l}\text { Management of solid wastes: Collection, } \\
\text { transport and final disposal of solid wastes }\end{array}$ & Not applicable & 86 & 4.72 \\
\hline & 15 & $\begin{array}{l}\text { Percentage of control measures executed } \\
\text { regarding those programmed }\end{array}$ & $100 \%$ & 82 & 4.49 \\
\hline & 16 & $\begin{array}{l}\text { Percentage of mitigation measures } \\
\text { executed regarding those programmed }\end{array}$ & $100 \%$ & 93 & 5.08 \\
\hline & 17 & $\begin{array}{l}\text { Percentage of audits executed regarding } \\
\text { those programmed }\end{array}$ & $100 \%$ & 83 & 4.53 \\
\hline \multirow{2}{*}{$\underset{\infty}{\complement}$} & 18 & $\mathrm{~N}^{\circ}$ of inspections of facility quality & 5 yearly & 89 & 4.87 \\
\hline & 19 & $\mathrm{~N}^{\circ}$ of inspections of equipment operation & 4 yearly & 87 & 4.77 \\
\hline
\end{tabular}




\begin{tabular}{|c|c|c|c|c|}
\hline 20 & $\mathrm{~N}^{\circ}$ of preventive maintances of facilities & 2 yearly & 89 & 4.87 \\
\hline 21 & $\mathrm{~N}^{\circ}$ of corrective maintances of facilities & 2 yearly & 82 & 4.49 \\
\hline & & & & 100 \\
\hline
\end{tabular}

\section{APPLY THE GENERATED TOOL}

The sustainability performance evaluation methodology was applied to 5 building projects in Peru (Table 4), in order to obtain quantitative results regarding their sustainability performance key indicators (KPIs). The method consisted of assigning the maximum score of each indicator if its compliance was evidenced, or otherwise, a proportional score was assigned. The summary table (Table 5) shows the management practices implemented in the projects under analysis and their relationship with their sustainability performance.

Table 4: Description of the buildings

\begin{tabular}{cccccc}
\hline Project Details & $\mathbf{N}^{\circ} \mathbf{0 1}$ & $\mathbf{N}^{\circ} \mathbf{0 2}$ & $\mathbf{N}^{\circ} \mathbf{0 3}$ & $\mathbf{N}^{\circ} \mathbf{0 4}$ & $\mathbf{N}^{\circ} \mathbf{0 5}$ \\
\hline Use & Offices & Offices & Offices & Offices & Offices \\
Floors & 10 & 30 & 18 & 27 & 6 \\
Basements & 4 & 4 & 8 & 10 & 5 \\
Built area & $30.146 \mathrm{~m} 2$ & $66.580 \mathrm{~m} 2$ & $27.452 \mathrm{~m} 2$ & $35.000 \mathrm{~m} 2$ & $9.792 \mathrm{~m} 2$ \\
\hline
\end{tabular}

Table 5: Summary table - Evaluation of sustainability performance.

\begin{tabular}{cccccc}
\hline \multicolumn{5}{c}{ Evaluation of sustainability performance } \\
\hline Project Details: & $\mathbf{N}^{\circ} \mathbf{0 1}$ & $\mathbf{N}^{\circ} \mathbf{0 2}$ & $\mathbf{N}^{\circ} \mathbf{0 3}$ & $\mathbf{N}^{\circ} \mathbf{0 4}$ & $\mathbf{N}^{\circ} \mathbf{0 5}$ \\
Lean Practices & $\checkmark$ & $\checkmark$ & $\checkmark$ & $\checkmark$ & $\checkmark$ \\
$\begin{array}{c}\text { Environmental } \\
\text { management }\end{array}$ & $\checkmark$ & $\checkmark$ & $\checkmark$ & $\checkmark$ & $\checkmark$ \\
LEED Certification & $\checkmark$ & $\checkmark$ & $\checkmark$ & $\times$ & $\times$ \\
Obtained Score: & 16 & 16 & 16 & 3 & 11 \\
Design & 60 & 63 & 56 & 26 & 40 \\
Construction & Not & 19 & Not & Not & 12 \\
Use & applicable & & applicable & applicable & \\
Total (points) & 76 & 98 & 71 & 29 & 62 \\
\hline
\end{tabular}

\section{EVALUATE RESULTS}

Initially, the maximum score reached among the projects evaluated was 98 points, because the unit of measure of the indicator: Number of meetings between the production departments and environmental management, according to the experts' opinion indicated twice a week. However, after analyzing the results, it was concluded that construction companies are convinced to make just one meeting a week when detailed scheduling is carried out, as well as sectorization, BIM level of detail and collaborative work (Ballard et al., 2003). Therefore, after this indicator revision, the unit of measure was modified to 
1 weekly meeting, such amount is related to the practices of the Lean Construction philosophy.

Finally, with this readjustment, a project reached the maximum score of 100 points, consistent with a synergic work between the production and environmental management departments.

Next, the implementation of the tool to evaluate the sustainability performance of the building projects showed that the collaborative work between the production management and the environment departments allowed a greater effectiveness of sustainability in the building projects.

Therefore, the construction companies that do not integrate production management practices with the environmental management department (Project $\mathrm{N}^{\circ} 04$ ) are showed to have a poor performance of sustainability in comparison to the companies where they are starting to perform synergic work (Projects $\mathrm{N}^{\mathrm{o}} 03$ and 05), are in the improvement phase (Project $\mathrm{N}^{\mathrm{o}}$ 01), or are already assuming a responsible role with the environment (Project $\mathrm{N}^{\mathrm{o}}$ 2).

\section{RESULTS REPORT}

The results obtained for the different projects are analyzed, and if poor management practices are detected, improvement alternatives will be suggested in order to improve the sustainability performance of the building projects.

\section{CONCLUSIONS}

The proposed tool is flexible and easy to be implemented. It contributes to the improvement of the sustainability indicators of the building projects because it allows identification of the poor practices of the construction companies in a timely manner by analyzing the indicators where they obtained the lowest scores. In this way, once the departments to be improved are located, the opportunity for companies to optimize their environmental practices is opened.

The research work revealed the importance of the design stage in comparison to the later phases, since poor planning and lack of compatibility between the different departments of the project will be reflected in the following phases by generating additional and cost overruns, as well as greater use of materials and greater generation of waste. Consistent with this statement, the panel of experts provided the highest score to indicators $\mathrm{N}^{\mathrm{o}} 01$ and 03 , corresponding to the project design phase.

The collaborative work between the production management and the environment department allows a greater effectiveness of sustainability in building projects. This statement is consistent with the results obtained during the implementation of the tool for the evaluation of sustainability performance in building projects.

We can conclude that a sustainability performance evaluation methodology was developed integrating the Last Planner System and sustainability management, and validated using the Delphi method. The protocols corresponding to the evaluation of the design, construction, and use phases of the buildings were developed and validated, and successfully applied to five case studies, analyzing the results, and validating the methodology.

The proposed model should be complemented with a subsequent spread phase and a larger-scale implementation in order to validate its contribution to improving the sustainability performance of construction companies. 


\section{REFERENCES}

Ansah, R.H. and Sorooshian, S. 2017. "Effect of Lean Tools to Control External Environment Risks of Construction Projects." Sust. Cities and Soc., 32: 348-356.

Ballard, G., and Howell, G. 2003. "An update on last planner." Proc. $11^{\text {th }}$ Ann. Conf. Int. Group for Lean Constr. (IGLC-11), Blacksburg, Va., 22-24 July, pp. 11-23.

Brioso, X. and Patricio, W. 2017. "Identification and evaluation of satisfaction degree in the post-occupation phase of the economic housing projects from the perspective of the users: Peruvian case study." Ann. of Build., 3(2) 17-26.

Brioso, X. 2011. "Applying Lean Construction to Loss Control". Proc. 19 $9^{\text {th }}$ Ann. Conf. Int. Group for Lean Constr. (IGLC-19), Lima, Peru, 13-15 July, pp. 13-15.

Carneiro, S.B.M., Campos, I.B., De Oliveira, D.M., Barros Neto, J.P. 2012. "Lean and Green: a relationship matrix." Proc. $20^{\text {th }}$ Ann. Conf. Int. Group for Lean Constr. (IGLC-20), San Diego, USA, 18-20 July.

Carvajal-Arango, D., Bahamón-Jaramillo, S., Aristizábal-Monsalve, P., VásquezHernández, A., and Botero Botero, L. F. 2019. "Relationships between lean and sustainable construction: Positive impacts of lean practices over sustainability during construction phase." J. of Cleaner Production, 234: 1322-1337

Cortes J.M.; Pellicer, E.; Catalá, J. 2012. "Integration of occupational risk prevention courses in engineering degrees: Delphi study." $J$. of Professional Issues in Engineering Education \& Practice, 138 (1) 31-36.

Cruzado, L.F. 2019. "Evaluation of sustainability performance in building projects, integrating the Lean Construction philosophy and sustainable management using the Delphi method." Pontifical Catholic University of Peru, pp. 54-65

Degani, C.M., Cardoso, F.F. 2002. "Environmental performance and lean construction concepts: Can we talk about a clean construction?" Proc. $27^{\text {th }}$ Ann. Conf. Int. Group for Lean Constr. (IGLC-27), Dublin, Ireland, 1-7 July, pp. 1-13.

Du Pisani, J.A. 2006. "Sustainable development e historical roots of the concept." Environ. Sci., 3 (2) 83-96.

Elkington, J. 2013. "Enter the Triple Bottom Line.” The Triple Bottom Line, pp. 1-16.

Francis, A., and Thomas, A. 2019. "Exploring the relationship between lean construction and environmental sustainability: A review of existing literature to decipher broader dimensions." Journal of Cleaner Production, 252: 119913.

Hallowell, M.R. and Gambatese, J.A. 2010. "Qualitative research: application of the Delphi method to CEM research". Journal of Construction Engineering and Management, 136 (1) 99-107.

Horman, M.J., et al. 2006. "Delivering green buildings: process improvements for sustainable construction." J. Green Build., 1 (1) 123-140.

Horvath, A. 2004. "Construction materials and the Environment". Ann. Rev. Environ. Resour., 29: 181-204.

Hsu, C.C; and Sandford, B.A. 2007. "The Delphi technique; Making sense of consensus." Practical assessment, research and evaluation, 12 (10) 171-194.

Huovila, P., Koskela, L. 1998. "Contribution of the principles of lean construction to meet the challenges of sustainable development." Proc. $\sigma^{\text {th }}$ Ann. Conf. Int. Group for Lean Constr. (IGLC-6), São Paulo, Brazil, August, pp. 13-15.

Hussin, J.D., Rahman, I.A. and Memon, A.H. 2013. "The Way Forward in Sustainable Construction: Issues and Challenges." Int. Journal of Advances in Applied Sciences, 2 (1) $31-42$. 
Jørgensen, F., Matthiesen, R., Nielsen, J., Johansen, J. 2007. "Lean Maturity, Lean Sustainability." Advances in production management systems. 246: 371-378.

Kim J-W, Bae, Youg-Woo. 2007. A. "Sustainable Value in Construction Project and Application of Lean Construction Method." Proc. 15th Ann. Conf. Int. Group for Lean Constr. (IGLC-15), Michigan, USA.

Koranda, C., Chong, W. K., Kim, C., Chou, J.-S., and Kim, C. 2012. "An investigation of the applicability of sustainability and Lean concepts to small construction projects." KSCE J. Civ. Eng., 16 (5) 699-707.

Koskela, L. 2000. "An Exploration towards a Production Theory and its Application to Construction." PhD Dissertation, VTT Building Technology, Espoo, Finland, 408: 296

Koskela, L., Ballard, G., Howell, G., Tommelein, I. 2002. "The foundations of lean construction." Des. Constr. Build. Value, Oxford, UK, pp. 211-226.

Landeta, J. 2006. "Current validity of the Delphi method in social sciences." Technological Forecasting and Social Change, 73 (5) 467-482.

Lapinski, A.R., Horman, M.J., Riley, D.R. 2006. "Lean processes for sustainable Project delivery." J. Constr. Eng. Manag. 132 (10) 1083-1091.

Li, L., Li, Z., Li, X., Zhang, S., and Luo, X. 2020. “A new framework of industrialized construction method in China: Towards on-site industrialization." Journal of Cleaner Production, 244: 118469.

Manzini, E., Bigues, J. 2000." Sustainability and discontinuity." Ecology and democracy: from ecological injustice to environmental democracy, Barcelona, Spain, pp. 12-14.

Mossman, A. 2009. "Creating value: A sufficient way to eliminate waste in lean design and lean production." Lean Constr. J., pp. 13-23.

Peng, W., Pheng, L.S. 2011. "Lean production, value chain and sustainability in precast concrete factory - A case study in Singapore.” Lean Constr. J., pp. 92-109.

Rajendran, S., Gambatese, J.A., Behm, M.G. 2009. "Impact of green building design and construction on worker safety and health." J. Constr. Eng. Manag. 135 (10) 10581066.

Scofield, J. H. 2013. "Efficacy of LEED-certification in reducing energy consumption and greenhouse gas emission for large New York City office buildings." Energy and Buildings, 67: 517-524

Solaimani, S., and Sedighi, M. 2019. "Toward a holistic view on Lean sustainable construction: a literature review." Journal of Cleaner Production, 248: 119213

Stern, N. 2006. "The Economics of Climate Change: The Stern review." Cambridge University.

United Nations Environment. 2018. "Sustainable Buildings.”. Accessed October 15, 2018. https://www.unenvironment.org/explore-topics/resource-efficiency/whatwedo/cities/sustainable-buildings.

Vieira de Carvalho, A.C., Granja, A.D., Gomes da Silva, V. 2017. "A systematic literature review on integrative lean and sustainability synergies over a building's lifecycle." Sustain., 9 (7) 1156.

Weinheimer, N. 2016. "The process of green building Certification: an examination regarding lean principles." Proc. 24th Ann. Conf. Int. Group for Lean Constr. (IGLC24), 20-22 July, Boston, USA, pp. 53-62. 